JAROSLAV BURIAN, STANISLAV ŠŤASTNÝ, JAN BRUS, VILÉM PECHANEC, VÍT VOŽENÍLEK

\title{
URBAN PLANNER: MODEL FOR OPTIMAL LAND USE SCENARIO MODELLING
}

BURIAN, J., ŠŤASTNÝ, S., BRUS, J., PECHANEC, V., VOŽENÍLEK, V. (2015): Urban Planner: model for optimal land use scenario modelling. Geografie, 120, No. 3, pp. 330-353. - This paper describes a new approach to automatic optimal land use scenario modelling using the developed ArcGIS "Urban Planner" extension. The first part of the paper addresses the implementation of geoinformatic technologies in spatial planning. The study presents several models and approaches, which focus mainly on the evaluation of land suitability, spatial modelling, and the possibilities of their use in urban planning. The main part of the paper describes the theoretical basis of the model, which is built on a weighted raster overlay. This study also elaborately analyses the functionality of the extension, which lies in the assessment of land suitability and the detection of optimal areas suitable for urban development. The paper also offers some testing of the model, specifically its robustness and sensitivity in the Olomouc region and its possible use for the creation of development scenarios.

KEY WORDS: ArcGIS extension - Urban Planner - urban planning - land suitability optimal land use - scenario modelling.

This paper was supported by the project nr. CZ.1.07/2.3.00/20.0170 co-financed by the European Social Fund and the national budget of the Czech Republic.

\section{Introduction}

Spatial planning is a considerable component of the rapidly developing geosciences. Many new methods and modelling techniques, such as GIS (Geographical Information Systems), GPS (Global Positioning Systems) and remote sensing techniques, have been developed and applied in various aspects of spatial planning during the last decade (Burian et al. 2012). Rapid advances in GIS technology in recent years have greatly expanded the utility of GIS and the scope of application of these spatial data management tools (Laurini 2001, LeGates 2005). Many current GIS applications do not exploit the full capacity of GIS techniques to meet the information needs of top-level management (LeGates, Stout 2000).

The spatial aspect of planning processes invites the use of modern geoinformatic technologies. Thus, in the last decade, such technologies have become an almost integral part of state administration and its administrative units. Planning processes, in addition to other things, make the operation of state administration more effective and precise (Burian, Štávová 2009). Unfortunately, spatial planning sometimes strives for the best distribution of human 
activities without regard for environmental conditions. However, environmental conditions should play an essential role in spatial planning. In practice, it often happens that new buildings are built in places unsuitable for human activities (floodplains, landslide areas), thereby leading to a conflict between physico-geographical conditions and human activities, both existing and proposed (Pechanec et al. 2011).

A number of authors engage with the topic of land suitability assessment. Works focused on land planning issues include those by Baran-Zglobicka (2004); Kenderessy (2003); Picher, Romero-Calcerrada (2006); Kolejka (2001, 2003); Kolejka, Pokorný (2001) and Ružička (2000). Still, most of the cited authors used GI technologies on very limited levels, often as tools for visualization or simple analysis. They did not use its advanced techniques. GIS tools in the form of overlay analyses are used, e.g., in multi-criteria decision-making concerning optimal land uses or in the detection of changes due to the gradual development of various spatial systems (Hlásný 2007). Kolejka, Pokorný (1999), Kolejka (2001, 2003) and Pouš, Hlásný (2005) address similar issues. Using GIS methods, it is possible to identify unsuitable areas for urbanization and city development, making it possible to aim strategies for regional development in other places. The simulation results of urban processes in a studied area can serve as several suggested development scenarios to be compared (Burian et al. 2008).

Laurini (2001) introduces the most interesting software for the purposes of urban planning for areas of different sizes. He emphasises DSS (Decision Support Systems) - tools for decision-making support that can be used for urban planning for greater territorial units. The topic of DSS and SDSS (spatial decision support system) is also one of the most discussed topics in spatial planning (e.g. Kalogirou 2002; Verstegen et al. 2012). Laurini (2001), however, is the first to deal with the issue of implementing information systems (GIS in narrower sense) in urban planning in detail. He evaluates GIS not only as a tool for high-quality visualisation but also as a tool for processing spatial analyses, modelling, making prognoses, setting scenarios of development for areas or multi-criteria decision-making (Pettit, Pullar 1999; Ma et al. 2007). Very common approaches in urban modelling address cellular automata (Batty, Xie, Sun 1999; García et al. 2012), agent-based modelling (Feitosa, Le, Vlek 2011; Magliocca et al. 2011), land use changes and optimization (Marjanovic et al. 2012; Silveira, Dentinho 2010; Cao et al. 2012) and spatial structures (Burian et al. 2012; Burian, Brus, Voženílek 2013).

Current advances in spatial planning and modelling have induced the development of many different computer models. Klosterman, in his numerous publications (e.g., Klosterman 1999), describes his own software solution for creating scenarios - the tool "What if?" - which belongs to a group of planning support systems (PSS) and is an extension of the Esri products. Brail and Klosterman (2001) describe in their book several programmes (METROPILUS, INDEX, TRANUS, CUF I, CUF II or CURBA) that are commonly used for the purposes of regional planning, primarily in the USA but also in other countries. The use of the ArcGIS Model Builder tool for regional planning around Munich is described by Schaller (2007). Maantay and Ziegler (2007) introduced several examples of applications of the GIS analytical tools for urban environments. 
LADSS (Land Allocation Decision Support System) is described by Matthews, Sibbald, Craw (1999) as a computer-based land use planning tool developed by the Land Use Systems Programme of the Macaulay Institute. In their paper, Bougromenko and Zakirov (1999) describe Geogracom 5W as an expert system with a transport network database built on the knowledge of several transport specialists with the application of decision rules. SUDSS (Spatial understanding decision support system) is described by Jankowski and Stasik (2001) as an Internet-based software prototype of a distributed collaborative work environment for a series of experiments in space and time (Burian 2008). Zwick and Carr (2007) introduced LUCIS (Land-Use Conflict Identification Strategy) as a strategy to explore the optimal suitability of three broad land-use categories (agriculture, conservation and urban) and compare them to identify whether there are any conflicts. LUCIS has also been introduced as a tool with the potential for many other applications, including strategic conservation planning, real estate investments, infrastructure planning or general market analysis (Pechanec et al. 2011). He et al. (2006) describe the issues of scenarios of development in connection with a model of urban expansion (UES). Other authors dealing with the issue of scenarios of development include Vorel, Maier, Grill (2007); Ligmann-Zielinska, Jankowski (2010); Zhang et al. (2011) and Petrov et al. (2006), who describe the creation of regional scenarios for several places in Europe and China.

Probably the most developed model for urban modelling was developed by the interdisciplinary research group of the University of Washington in Seattle (now working at the University of California, Berkeley, in 2015). The software-based simulation models "Urban SIM" and "Urban Canvas" are tools for integrated planning and analysis of urban development, incorporating the interactions between land use, transportation, and public policy (Burian 2008). The basic principles of this software and model are described in many articles (e.g. Waddell 2002; Alberti, Waddell 2003; or Borning, Waddell, Förster 2007). Urban SIM software is licensed under GNU (General Public License), which means it is free, open-source software and can be changed for personal use. Using the model makes it possible to create several scenarios of landscape development. Alberti and Waddell (2003) state that the model can be executed for a given scenario and the results of one or more scenarios can be examined and compared.

In Czechia, urban planning research using GIS is not as developed as in the mentioned countries. In general, Czech geographers deal with urban modelling issues only on a very limited level (Vorel, Mairt, Grill 2007; Vorel, Maier, 2007; Maier, Vorel, Čtyroký 2007a; Maier, Vorel, Čtyroký 2007b; Grill, Vorel, Maier 2008). Standard procedures for urban planning do not include any type of spatial analysis to evaluate land suitability by objective or using a unified approach. Most of the proposals are based on the authors' experiences and follow only strict rules (limits). These proposals are not based on any calculations, and it is very difficult to compare them with other areas. This process can lead to proposing new activities in unsuitable areas with low land suitability. Further, some proposals can be suggested in places with very high suitability for another activity. The difficulties in implementing the mentioned models in Czech urban planning arise from different data structures. 
In addition, most of the models are created for larger areas and the scales of the results are too small (too general) for detailed urban planning. For these reasons, the authors of this paper created a model that could create better conditions for the development of urban modelling in Czech urban and spatial planning. The main objective was to create a model that would be usable in the Czech geographic space, used Czech datasets and respect contemporary legislation. The model was created to allow faster, more efficient and reproducible assessment of the land suitability which would minimize urban planners' opinion subjectivity. Part of the objectives was to create the model which would evaluate the entire territory under unified approach and thus limit the subjectivity in spatial selection. Because of this the results from the model are precisely localized in the space and could be used in practical land use planning. The practical component of the model was the main reason for developing not only a theoretical model but also a software tool.

The model is capable of working with data available at local planning offices according to the Act no. 500/2006 Coll. A large advantage of this solution is the availability of scaling of the results. The results are then fully applicable to the detailed level of planning (like cadastral maps). The outputs from the model can be used to detect areas with the highest land suitability for the selected category of land use. Several scenarios of land suitability and land development can be created, and the user can determine which scenario has the highest potential in the chosen location. The extension can be used not only for the creation of urban plans but also for the evaluation of urban plans or to search for areas suitable for future development. According to the results, it is also possible to verify whether current or proposed activities correspond to the areas with the highest land suitability. Based on the similarities and differences, it is possible to determine what factors were omitted during the creation of the corresponding urban plan and what should be improved in the next steps.

\section{Arc GIS Extension Urban Planner}

Urban Planner, as described in this paper, in an extension of the programme Esri ArcGIS that makes it possible to perform calculations of land suitability and optimal land use and to create scenarios of possible urban development. When the concept of the functionality of the Urban Planner extension was being created, the methodology LUCIS (Zwick, Carr 2007), the methodology LANDEP (Ružička 2000), the model What if? (Klostermann 1999), and the methodology of optimal land organisation (Kolejka 2001, 2003) were used as the main references. The extension offers an original approach to land suitability evaluation - from both theoretical and practical points of view.

To function properly, the extension Spatial Analyst and Python 2.5 (or higher) must be installed. The extension was programmed with programming languages Visual Basic 6.0 and Python 2.5 (which makes it possible to use geoprocessing objects from ArcGIS). To create registers and dynamic libraries, the tool ESRI ArcGIS Desktop Software Developer Kit for Visual Basic 6 was used. The toolbar of Urban Planner is composed of four basic elements: "Land suitability", "Optimal land use", Settings and Help. 
The extension was created following the introduction of a new Construction Code and Act no. 500/2006 Coll., which addresses regional analytic planning data, regional planning documentation and a register of regional planning activity. The extension works with data in the Esri shapefile format. Regional analytic planning data (data at a scale of 1:5,000-1:25,000) can be used as the main source of data. An integral part of the data is polygons, which define the spatial extent of an area of interest. The input data are vectors. However, for the purposes of assessment, the model converts the necessary layers into raster format. The final output of the assessment process is raster layers of land suitability for each individual activity, a vector layer of the suggested functional use of an area and text results (paths to created data, information about the weights of the input factors, and a statistical summary of the data characteristics - minimum, maximum, average, dispersion and standard deviation).

\subsection{Components of land suitability assessment}

The first part of the extension is an assessment of land suitability for a certain activity. The solution offers an assessment of both physico-geographical and socioeconomic factors, which are evaluated separately. The assessment scale of suitability factors and weighting factors ranges between 0 and 10 . The model works with vector data as an input and a raster layer as an output. Land suitability is calculated for the following categories: housing areas, industrial areas, sports and recreation areas, public facility areas and commercial infrastructure areas. These categories and physico-geographical and socioeconomic factors (Table 3) were chosen after several discussions with urban planners to cover the important categories that influence urban development. The assessment of land suitability is conducted at three levels:

1. The highest level is used to set the weights of the physico-geographical and socioeconomic factors. The weights are determined by a ratio of percentages. If the weight of the physico-geographical factors is $40 \%$, that of the socioeconomic ones is $60 \%$. Thus, socioeconomic factors will have a greater influence on the result of a land suitability assessment.

2. The medium level is used to set the weights of each factor (Table 3). Each factor influences a monitored activity to a different degree, which represented by a weight for each factor. Each weight has a value from 1 (the least importance of a factor) to 10 (the highest importance of a factor). If a factor does not influence a future activity at all, it is assigned a value of 0 and is excluded from the analysis.

3. The lowest level is used to evaluate the suitability of factors. Factors (e.g., noise) can have both positive (e.g., silent environment) and negative impacts (e.g., noisy environment) on a future activity. As to the factors, it is essential to determine which parameter can be considered positive, neutral or negative, which is done according to the rating scale in Table 1 below.

Figure 1 describes this process from a technical point of view. At level 1, diagrams marked "ERL" represent so-called elementary (simple) raster layers. They are created by converting vector layers into a raster with an appropriate suitability value. When combining multiple layers (number $\mathrm{N}$ ) that represent 
Tab. 1 - Categories of factor suitability

\begin{tabular}{|ll|ll|}
\hline Assessment & Significance & Assessment & Significance \\
\hline 0 & Exclude & 5 & Average suitability \\
1 & The lowest suitability & 6 & Above-average suitability \\
2 & Very low suitability & 7 & High suitability \\
3 & Low suitability & 8 & Very high suitability \\
4 & Below-average suitability & 9 & The highest suitability \\
\hline
\end{tabular}

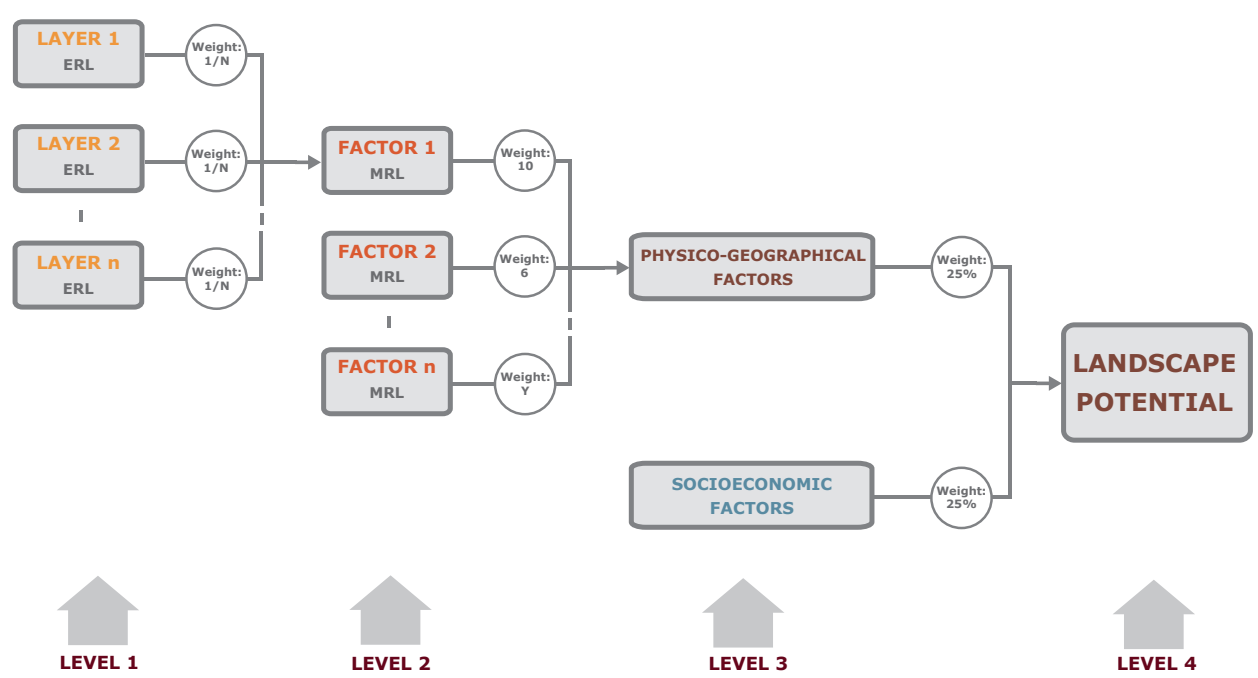

Fig. 1 - Scheme of land suitability calculation

one factor, all the layers are assigned the same weight (1/N). Using an algebra map, by counting up that rasters and subsequent dividing by that number, we obtain an "MRL" (multiple raster layer). The process is repeated for all the factors. At level 2, the new MRLs are multiplied by the weights (1 to 10) assigned to their importance. These rasters are again summed using the algebra map and after that divided by their number (M). In this way, multiple raster layers of classes of factors are calculated. At level 3, each class is multiplied by a particular percentage weight (again with the algebra map). They are then added together and divided by 100 . The result is a multiple raster layer of land suitability for a chosen activity. Land suitability takes on values from 0 to 9 . Value 0 represents an area that has been excluded as unsuitable. Other values of land suitability range from 1 to 9 . The theoretical value 9 applies to areas with absolute (ideal) suitability.

This theoretical concept is released in the extension as a toolbar "Assessment of land suitability" that consists of three windows: (1) setting physicogeographical factors, (2) setting socioeconomic factors and (3) setting weights of classes of factors. The first and second windows make it possible to set weights and to evaluate factor suitability (Fig. 2 and Fig. 3). The third window makes it 
Fig. 2 - Settings of physicogeographical factors

Fig. 3 - Settings of socioeconomic factors
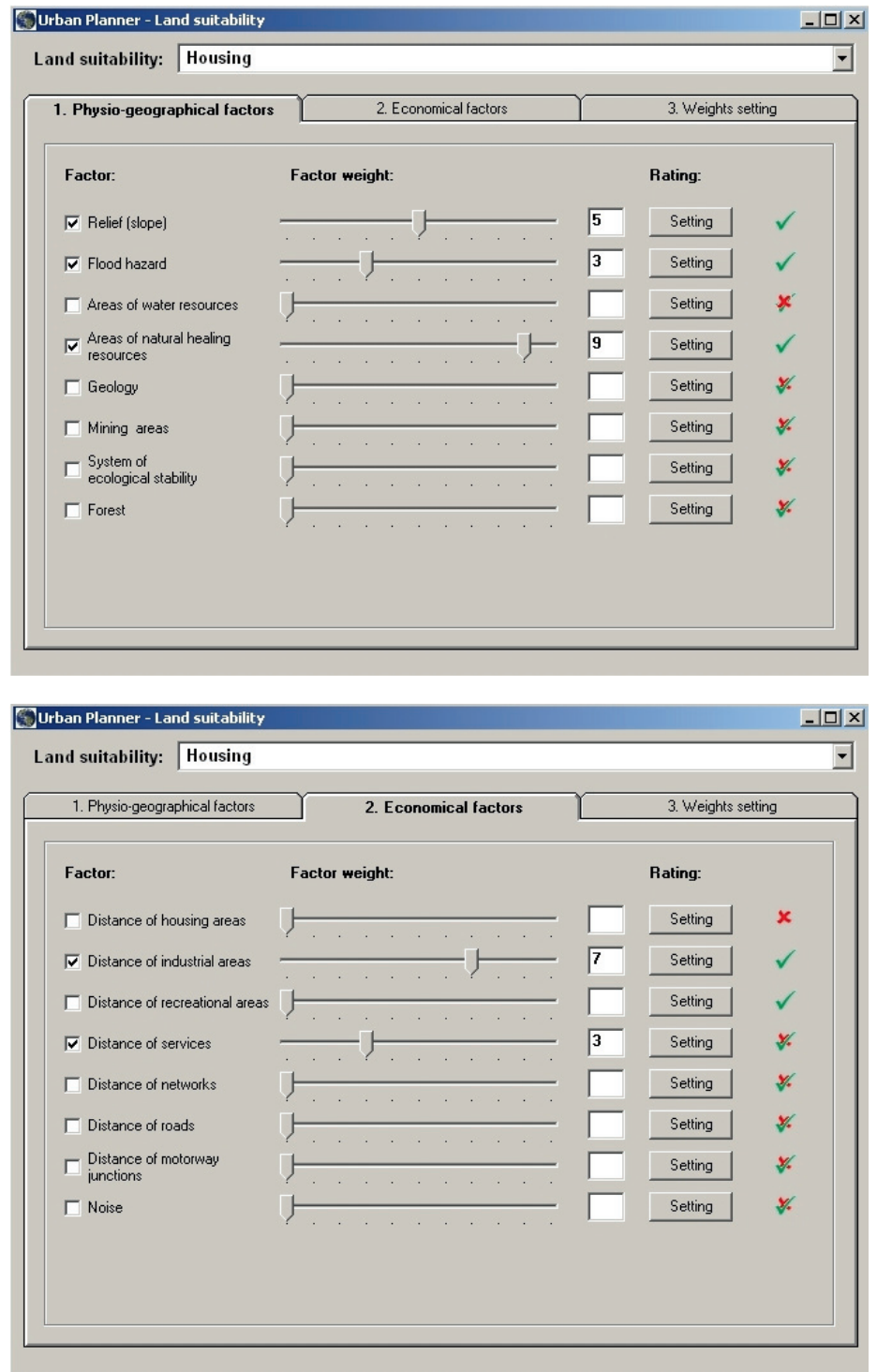

possible to set up the weight between physico-geographical and socioeconomic factors. All windows are composed of a series of check boxes that makes it possible to set whether a factor will enter the analysis of land suitability. If a factor is checked, further settings are available. The sliders are used to set the weights of the factors from 1 (the lowest) to 10 (the highest). Properly setting these factors is essential to obtaining the most accurate results of land suitability.

The output of the component is a landscape suitability raster (Fig. 4) of a monitored activity with values from 0 (no land suitability/areas excluded from the analysis) to 9 (highest land suitability). 


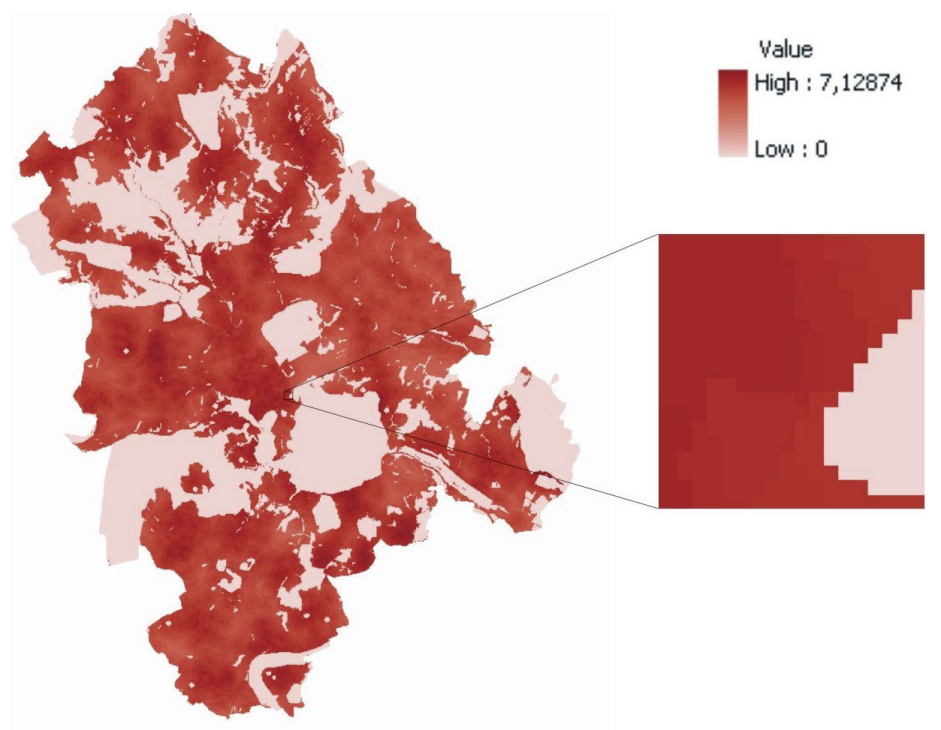

Fig. 4 - Example of results - land suitability for housing

Along with the created raster, a text file containing information about the results of the analysis is created. This file consists of paths to created data, information about input factor weights and a statistical summary of the nature of the data (minimum, maximum, average, dispersion, standard deviation).

\subsection{Components of optimal land use}

The second part of the extension involves a methodology for finding optimal land use based on the results from the first component (the calculation of land suitability). This part of the calculation can be divided into the following parts:

The first step is to differentiate the functional types of areas. The functional areas must contain individual categories that are appropriate for the monitored activities of the land suitability assessment. The other categories can be chosen arbitrarily. For the following procedure, it is essential to categorise rasters of land suitability into classes. Because the values of relative suitability are changeable and various factors can play a role in land suitability assessment, the classification is done with percentages. Default values are preset, as shown in Table 2.

The most significant part of the calculation compares the actual land use with rasters of land suitability.

Tab. 2 - Categories of land suitability

\begin{tabular}{|lcccccc|}
\hline & 0 & $0-30 \%$ & $30-50 \%$ & $50-70 \%$ & $70-85 \%$ & $85-100 \%$ \\
\hline Category & Excluded & Unsuitable & Low suit- & Average & High suit- & Very high \\
Abbreviation & NUL & UNS & Lowity & suitability & $\begin{array}{c}\text { ability } \\
\text { suitability }\end{array}$ \\
\hline
\end{tabular}




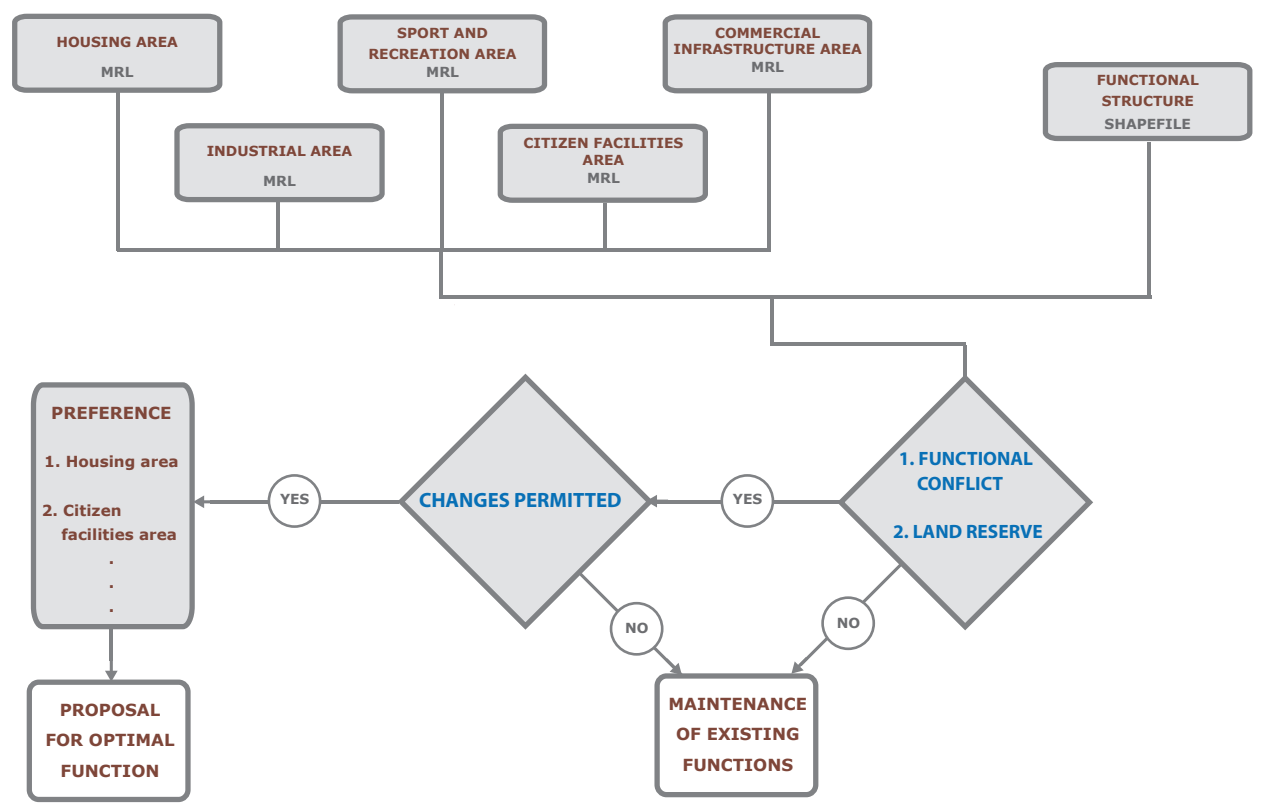

Fig. 5 - Scheme of optimal land use calculation

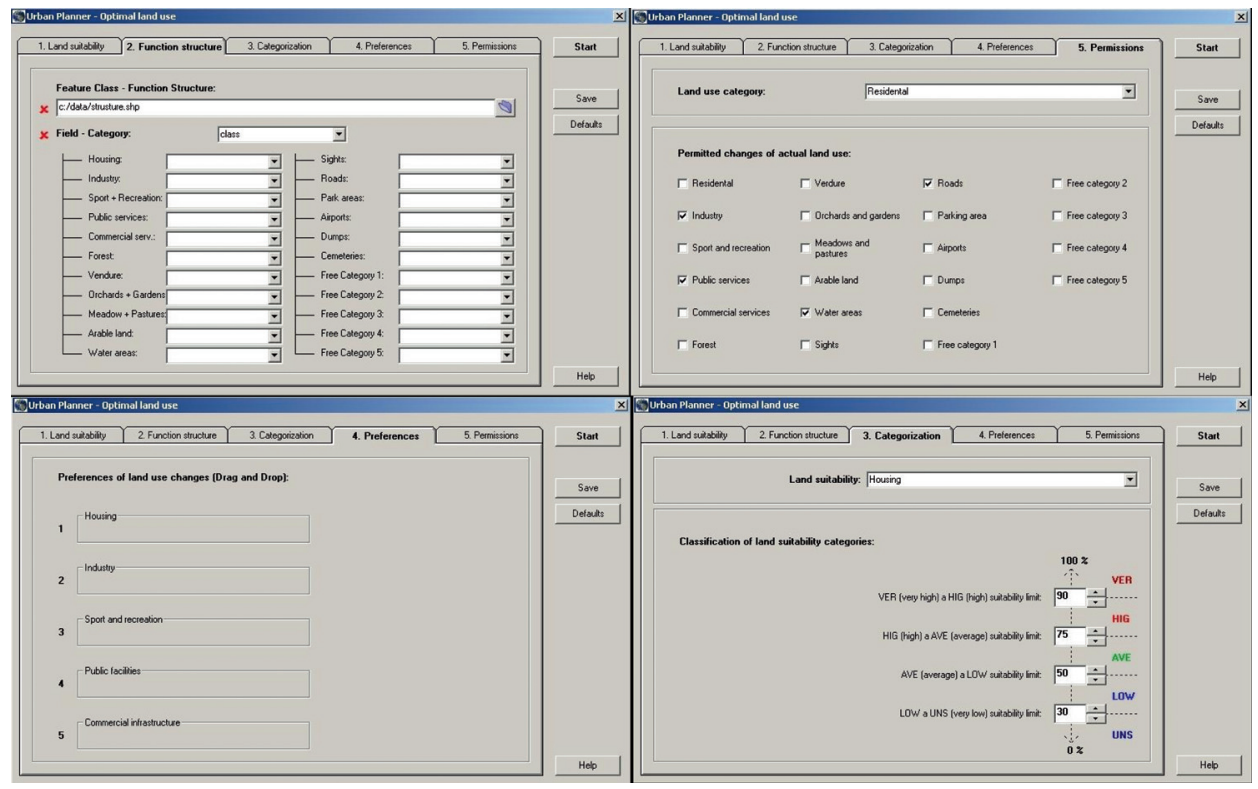

Fig. 6 - Extension environment for optimal land use calculation 
For each category of land suitability, land reserves (areas with high and very high suitability and with different land uses) and conflict areas (areas with low, unsuitable or excluded land suitability and existing land uses) are located.

Land reserves and conflict areas are aimed only at the localities where such a change in the current functional use is possible and economically tolerable. For each function, it must be set whether this change is possible. If land reserves and conflict areas are better for suggested functions, it is necessary to establish a sequence of functions according to the assumed significance of these functions. If there is a land reserve for more functions, the function that has been given greater significance in the sequence will receive priority.

The procedure of processing is shown in Figure 5. First, multiple raster layers (MRLs) of land suitability and shapefile functional area structures are loaded. A subsequent comparison of the values shows whether there is a land reserve or a functional conflict in the monitored area. Then, it is checked whether a change is feasible. If more areas meet the requirements, the one that has been given greater significance in the sequence of priorities is given preference. The result area is proposed for the optimal function. If no other function is found, the current function is maintained.

If no land reserve or conflict area is found in the monitored locality, the current function is considered to be optimal land use. If there is a land reserve or a conflict area found for only one urban activity and the current function is different, the activity is viewed as the optimal land use. If there are more suitable activities found for a given area, the one that has been given greater significance will be preferred.

This theoretical concept is released in the extension as the toolbar "Optimal land use", consisting of five windows (Figure 6 shows only 4 tabs, the step one with data loading is not significant to show): (1) loading land suitability data, (2) loading data and attributes of a functional structure of an area, (3) land suitability categorization, (4) preference of changes, and (5) allowance of changes.

The output of the component "optimal land use" is a vector layer in shapefile format that contains attribute fields with new information from the analyses. The layer contains information about the original land use, suggested (calculated) land use and all land suitability values.

\section{Extension Testing - Olomouc Region}

\subsection{Sensitivity testing}

Before the application of the Urban Planner extension in the selected area, the settings of the weights of the factors were tested. The testing was performed with the land suitability for housing. Other suitability factors are calculated in the same way, only with a different configuration of weighting factors and their parameters. Each parameter was evaluated with regard to the extent of its impact on the monitored area. The factors that have an average degree of suitability and a small areal extension affect the result minimally. The factors that have an extremely high or low degree of suitability and, at the same time, extend to a significantly large area (in proportion to the total size of a monitored 
Tab. 3 - Overview of setting factor weights at modelling final scenarios

\begin{tabular}{|lccccc|}
\hline Factor & Housing & Industry & $\begin{array}{c}\text { Sports } \\
\text { and } \\
\text { recreation }\end{array}$ & $\begin{array}{c}\text { Public } \\
\text { facilities }\end{array}$ & $\begin{array}{c}\text { Commercial } \\
\text { infrastructure }\end{array}$ \\
\hline Slope gradient & 5 & 8 & 8 & 5 & 5 \\
Flood risk & 10 & 10 & 4 & 10 & 10 \\
Water resource protection zone & 6 & 10 & - & 8 & 8 \\
Natural healing resource & 5 & 10 & - & 8 & 8 \\
protection zones & 5 & 8 & 10 & 8 & 8 \\
Geology & 10 & 10 & 10 & 8 & 8 \\
\hline Special protection areas & 10 & 10 & 10 & 8 & 8 \\
Territorial systems of ecological & 10 & 10 & 10 & 10 & 10 \\
stability & 2 & 8 & 6 & 2 & 6 \\
Forest areas & 6 & 2 & 8 & 2 & 2 \\
Distance from housing & 3 & - & 2 & - & - \\
Distance from industry & 3 & - & 1 & 2 & - \\
\hline $\begin{array}{l}\text { Distance from recreation } \\
\text { Distance from services }\end{array}$ & 10 & 10 & 6 & 10 & 9 \\
$\begin{array}{l}\text { Distance from utility systems } \\
\text { Distance from communications }\end{array}$ & 8 & 10 & 6 & 10 & 10 \\
Distance from significant & - & 2 & - & - & - \\
highway junctions & & & & & - \\
\hline $\begin{array}{l}\text { Noise } \\
\text { Protection zones of wastewater }\end{array}$ & 5 & 5 & 5 & 5 & 5 \\
treatment plants & 5 & 5 & 5 & 5 & 5 \\
Protection zones of electric & & & & & \\
power distribution network & 5 & & & & \\
\hline
\end{tabular}

area) affect the final result of land suitability more. Generally speaking, most factors affect the result to a large extent only when suitability is set to extreme values (maximum or zero value). According to the conducted testing, setting of weights of the physico-geographical and socioeconomic factors affects the result most significantly. The values of individual parameters and the weights of all physico-geographical and socioeconomic factors were constant; only the above-mentioned factor ratio was changed.

A total of 11 variants of land suitability values (with factor ratios of $0-100 \%$, at intervals of $10 \%$ ) were analysed. To evaluate the impact of changes in the monitored ratio on the final raster, the total statistical characteristics of individual rasters were compared, and the differences were visually evaluated. The outputs show that a change in the ratio between physico-geographical and socioeconomic factors significantly affects the results. There is a large change if the ratio is set to extremes (90:10). The greatest jump occurs when the ratio is set to 0:100 against the physico-geographical factors, which are excluded from the calculation. Most of these factors enter the calculations in the form of limits (e.g., protection zones) and normally act as hard factors, eliminating proposals of any activity at their place of occurrence.

When changing a factor ratio in favour of physico-geographical factors, minimum values rise, maximum ones fall, and the standard deviation is reduced. 
Suitability values become balanced, there is a smoother change of values, and extreme values have lower variance. If the ratio is 100:0 in favour of physicogeographical factors, a jump occurs again. This time, however, the changes in statistical indicators are significantly smoother than in the opposite case (because the size of socioeconomic areas with zero land suitability is much smaller).

If there is no group of factors completely eliminated from a calculation (by setting the ratio of 100:0), the size of zero suitability areas of the final raster is constant, and there is only a change in the suitability values of non-zero suitability areas. If the ratio is in favour of physico-geographical factors, the land suitability of the majority of areas is approximately 5 . In the opposite situation, the vast majority of values are spread over a wider interval, with a smaller number of each value (ranging from 3 to 6 ).

To set scenarios of development and to create a proposal of optimal land use, the weights of individual factors were set according to Table 3 . The weights were calculated with the commonly used Saaty method (Saaty 1983), which makes it possible to define the weights for several criteria as objectively as possible. Five urban planners from the City of Olomouc and Olomouc district were asked to use this method to evaluate the weights of all factors. There results were averaged to the values in Tab. 3 . To calculate various scenarios, the same settings of individual factors were used, with only the ratio between factors changed. The preference of changes in each area was also left at the same value for all calculations.

For a proposed optimal land use, the weights of the physico-geographical (PG) and socioeconomic (SE) factors were set to 50:50. This setting was also used for a scenario of development called "Compromise". To calculate the scenario "Man", the setting of 95:5 in favour of SE factors was chosen. In contrast, to calculate the scenario "Landscape", the opposite setting was selected (i.e., 95:5 in favour of PG factors). Such extreme settings were chosen because testing done at the ratio of 80:20, or vice versa, shows only minor changes. To be comparable and represent a certain type of development in an area, it was necessary to select extreme values that could affect the results to a larger extent.

\subsection{Results}

The main output of the model is three vector layers of a functional structure of an area for different scenarios of development, which carry attribute information about several calculated values (land suitability for housing, land suitability for industry, allowance of changes of a current functional structure of an area to a housing area, allowance of changes of a current functional structure of an area to an industrial area, optimal land use, categories of land suitability for housing, categories of land suitability for industry).

In the form of synthetic maps, Figure 7 and 8 illustrate the land suitability for housing and industry, which are the two most important categories related to urbanization processes. Land suitability is shown in three variants (scenarios). The first map (the scenario "compromise") shows the most likely variant of development for an area, or, more precisely, the proposed changes of 


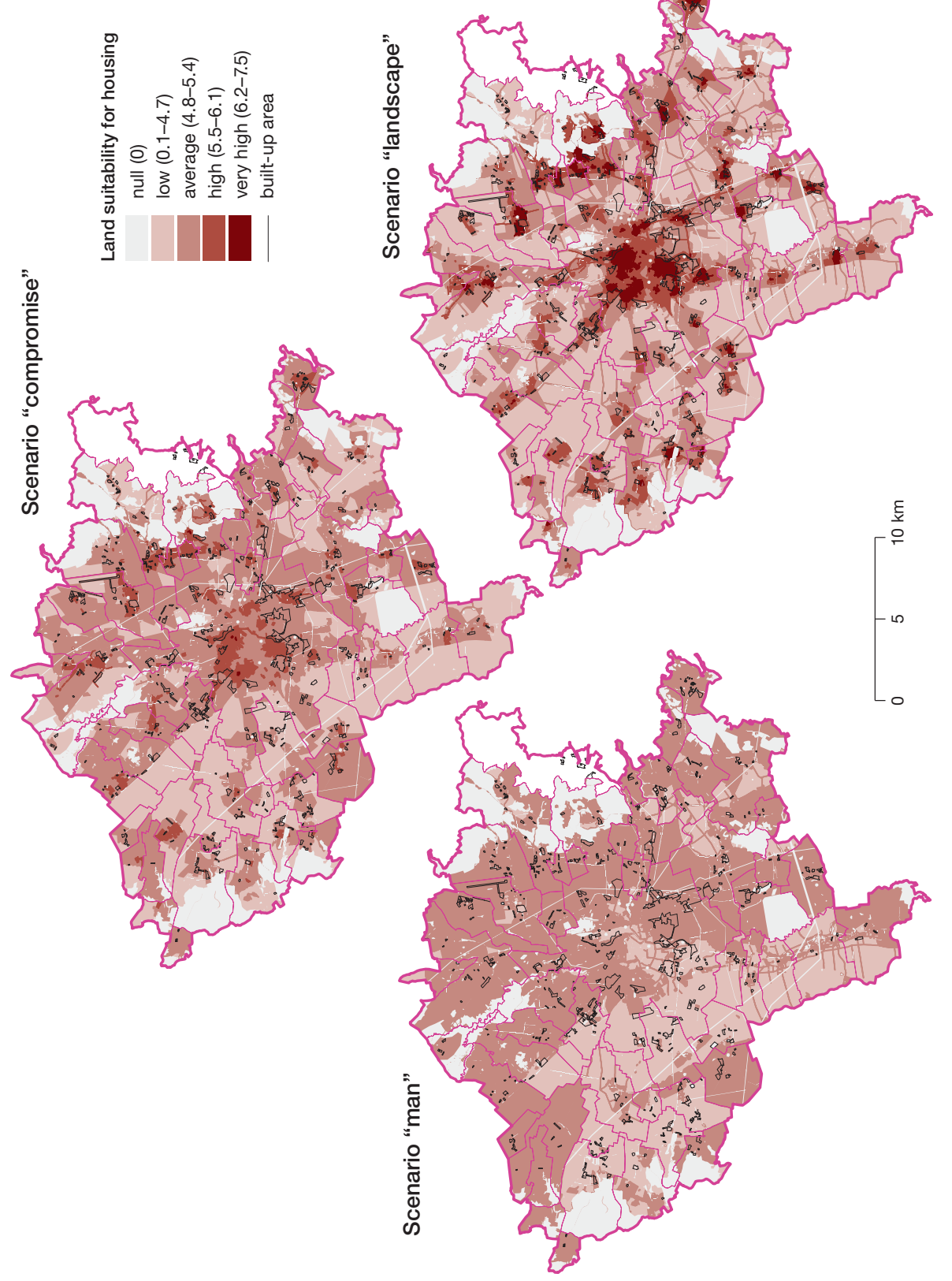

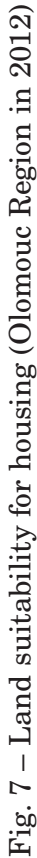




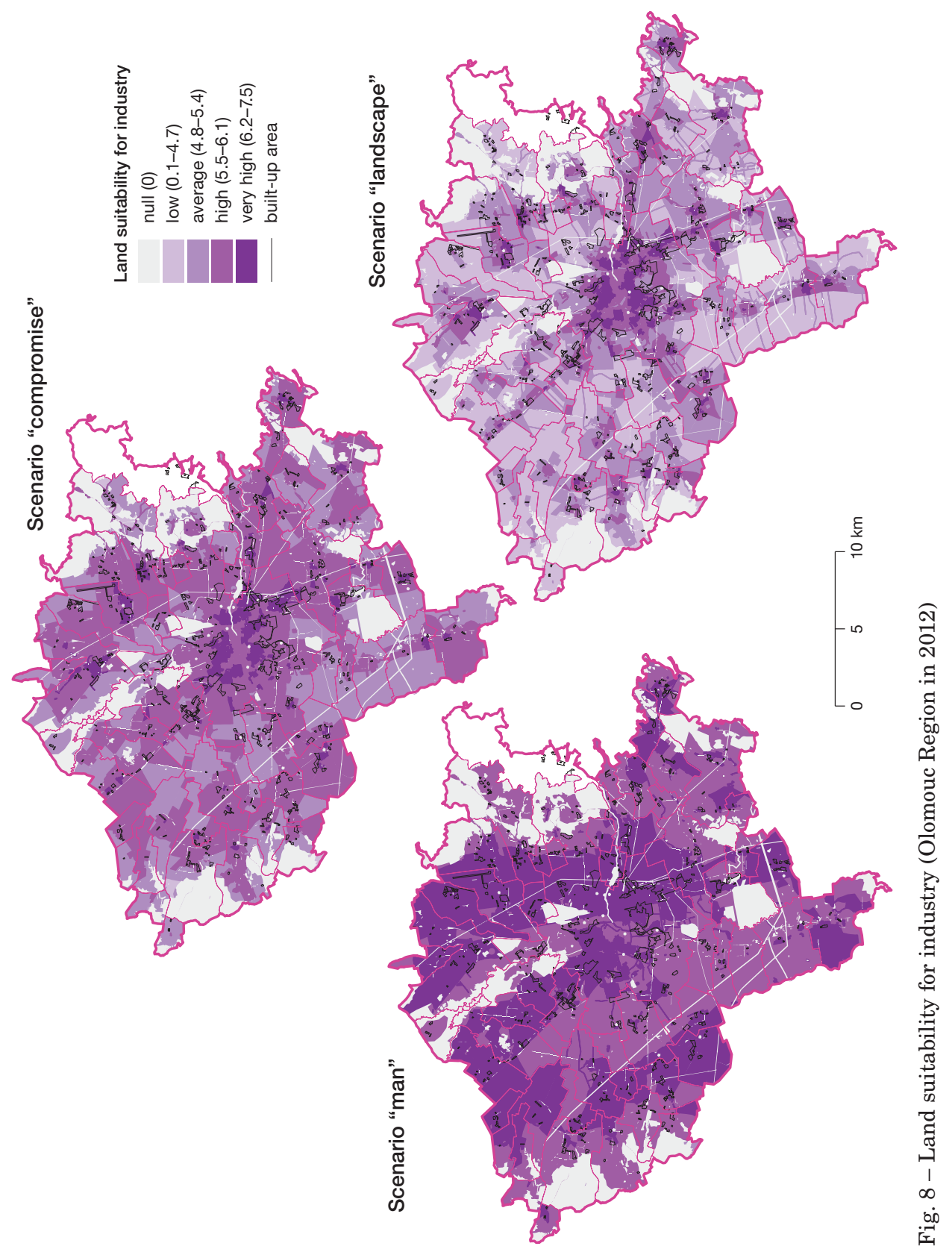


land use. The parameters of each input factor (50:50) were designed to model landscape characteristics as well as possible and thus bring the results of the analysis closer to a real future situation. The other two maps (the scenario "landscape" and the scenario "man") were modelled with a different setting of parameters in favour of one particular group of factors. The scenario "landscape" was set to have greater weight to physico-geographical factors at the expense of socioeconomic factors (95:5), and the scenario "man" was set the other way round.

According to results, it is possible to assess a localization of areas with different land suitability values for housing and industry with regard to the boundaries of current built-up areas as well as development areas. As for the scenario "compromise", the vast majority of high land suitability areas are located within or near built-up or development areas (as can be observed in both maps), which demonstrates the relevance of the results. Rarely, however, there are areas where the proposed land suitability is high in spite of the absence of built-up or development areas. There are also built-up or development areas where the calculated land suitability values are low, which may indicate a poor design of development areas.

In the case of the scenario "man", there exist a larger number of extensive areas with a high land suitability values situated not only close to built-up areas but also in the open countryside. This scenario takes into account a strong preference for development activities and shows the possible form of an area given a strong emphasis on the socioeconomic factors. As for the scenario "landscape", there is a preference for physico-geographical factors. The scenario emphasises the natural environment and expects a minimal development of built-up areas. Therefore, the scenario suggests only a smaller number of areas located very close to communications or built-up areas. Any development of the open countryside is limited.

Another synthetic map (Fig. 9) shows the total land suitability for the development of areas, i.e., the sum of individual land suitability factors for each functional area (housing, industry, commercial infrastructure, sports and recreation, and public facilities). The total land suitability correlates strongly with the built-up or development areas and indicates a high probability of development in a given territorial unit. The areas defined as the development areas are worth paying attention to, even if their calculated land suitability values are lower. Nevertheless, these areas (as well as the high land suitability areas in the development areas) are located throughout the whole territory.

The most important synthetic maps are shown in Figure 10 and illustrate the proposed changes in the current functional structure to an optimal functional structure in three possible scenarios of development. The scenario "compromise" shows the most likely development of an area - the optimal land use. The scenario demonstrates a reasonable number of newly proposed areas, most of which are located in the built-up or development areas. However, there are some areas that are proposed for housing in spite of being located outside the built-up or development areas. The most significant aspect of this map is probably a prediction of large industrial areas in the southeastern part of the city of Olomouc and close to Olomouc to the east. Both of them are predicted to be situated outside the built-up or development areas. Other functional 
areas are represented in the map more or less evenly, without any significant concentrations or surprising locations or sizes.

The scenario "landscape" shows the prediction of development of an area taking into consideration mainly socioeconomic factors. In the map, a decrease in all types of proposed areas can be noticed. Interestingly, there is a significant concentration of industry (particularly in the southeastern part of the city of Olomouc) and an extreme concentration of areas of sports and recreation in the northern part of the region.

The scenario "man" illustrates the predicted state of a landscape when the development is strongly influenced by physico-geographical factors. The map is at first sight very different from the previous variants, mainly because unlike in the previous scenarios, the proposed areas cover more than $50 \%$ of the entire territory. The extension proposes the location of sports and recreation areas in narrow strips to the north and to the south of the city of Olomouc. Housing areas are found in almost the entire area of interest.

The optimal land use according to the scenario "compromise" shows the optimal structure of the landscape of the area of interest in the form of a combination of current and proposed use. The more detailed analysis of all outputs enables us to speculate about the real future development of the area. The outputs indicate the likely expansion of industrial areas in the southeastern part of the city of Olomouc. New industrial buildings should, according to the calculated scenario, enlarge the existing built-up area and cover the area from the built-up area of the city of Olomouc to the southern motorway junction. Further development of industrial areas can be expected to follow the already existing industrial buildings situated in the eastern part of the city as well as in the villages situated close to the main roads.

The anticipated growth of housing areas can be divided into three categories. The first category is characterized by the construction of residential buildings in the outskirts of the city, following the existing built-up areas of the city, as suggested by the scenario "compromise". The second category is the likely enlargement of the built-up area situated in the eastern part of the city. However, these areas are dislocated and separated from the existing built-up area, and their formation is conditioned by the municipal plans of individual municipalities, which are often strongly influenced by local policies. The growth of these areas of housing is strongly conditioned by easy accessibility to the centre of the city (public transport, cycle lines), high environmental quality (outskirts of the city, forests) and a high level of attractiveness in general. The last category of growth is the classical construction of residential buildings in various smaller villages in the reaches of the city of Olomouc. Different from the above-mentioned cases, this growth is relatively spatially uniform (smaller areas are proposed for almost the entire area of interest) and subject to the particular conditions of individual villages, their overall possibilities and local policies. An increase in built-up areas (which, of course, brings about significant changes in the landscape) can be, according to the calculations, expected in several areas. 


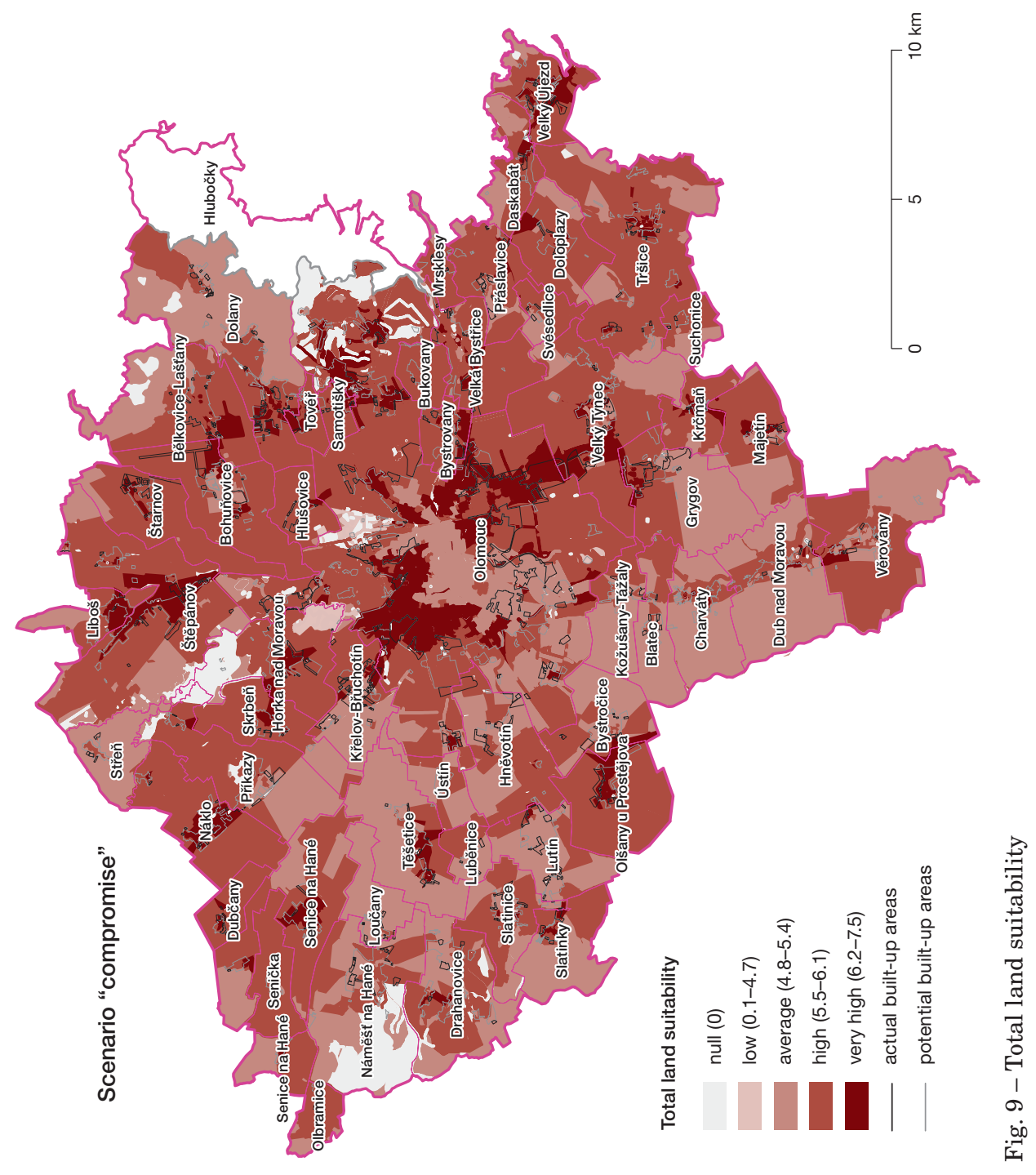




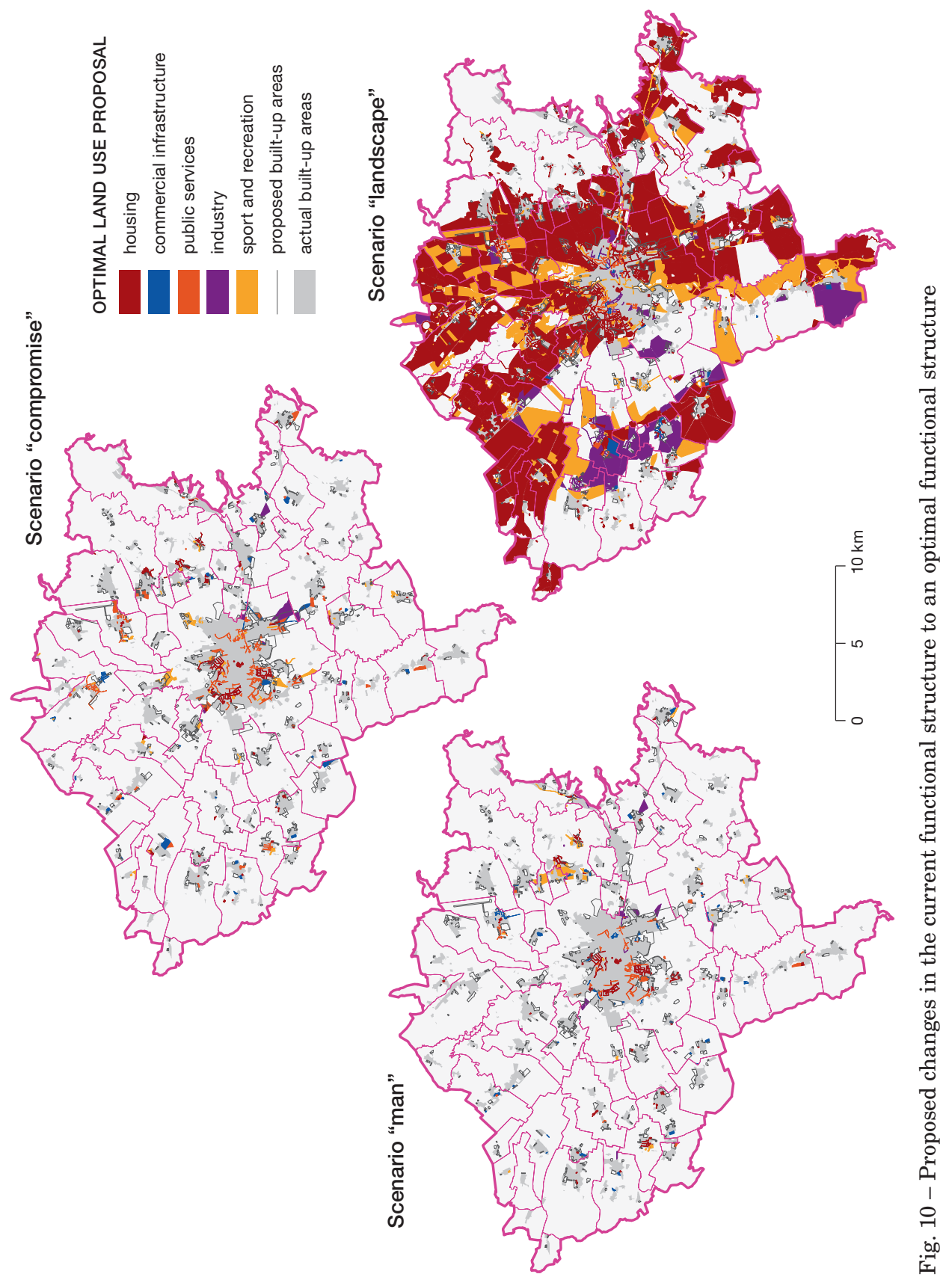




\section{Discussion and Conclusions}

This paper describes the extension "Urban Planner", which is the first software product of its type in Czechia. The extension was created based on the study of Czech and foreign approaches to the assessment of land suitability (Zwick, Carr 2007; Ružička 2000; Klostermann 1999; Kolejka 2001, 2003), finding conflicting areas and proposals of optimal land use. The described extension was used to introduce possible scenarios of development in the Olomouc region. The scenarios are displayed in the map appendices. The results are some of the first of their kind, prepared with a focus on the areas of municipalities with extended power (MEPs) and for specific purposes (i.e., modelling territorial development for the purpose of the strategic planning of the development of the region).

The issue of land suitability has been described by Ružička (2000) or Kolejka (2001, 2003). However, compared with our approach, these studies were performed on substantially smaller areas. Land suitability evaluation was done based on expert estimates (Ružička 2000) or without detailed discussions of the weights and parameters (Kolejka 2001, 2003), which is why it is very difficult to apply these approaches to other or larger areas, repeat these analyses at regular intervals or create several scenarios.

In comparison with existing models, Urban Planner is much more applicable not only as a new methodological approach but also as a practical tool for urban planning processes. Such models as UrbanSIM (Waddell 2002), LADSS (Matthews 1999), SUDSS (Jankowski, Stasik 2001) and Geogracom 5W (Bougromenko, Zakirov 1999) can create highly advanced results (especially UrbanSIM microsimulation sub-models). Suitable data (e.g., detailed data about income and traffic data) are needed to utilize them in Czechia. These data are very specific and missing on a detailed level. These situations make all the mentioned models virtually unusable.

The most similar approach uses the LUCIS model (Zwick, Carr 2007). LUCIS (Land-use Conflict Identification Strategy) uses only three broad land-use categories (agriculture, conservation and urban) and compares them to identify where conflicts exist. These three categories (Urban Planner uses 5 categories) can yield only general results for new development and do not offer the desired level of detail for planning. The technical solution (ArcGIS Model Builder) is a very unstable and unusable approach. Lastly, the model is applicable only for very limited purposes (smaller areas, limited number of layers). If any layer is missing, no calculation can be done with the LUCIS model.

A better environment for Czech planning purposes is the What If? model (Klostermann 1999), which has a structure very similar to the Urban Planner extension. With this model, land suitability and suggestions for new development can also be calculated. What makes this model unusable for Czech purposes is, once again, missing data (detailed land prices in this case).

For these reasons, the authors evaluate the Urban Planner extension, which is more applicable than the solutions from abroad. A strong connection (and the development of a connection) with the data used in Czech urban planning is one of the largest advantages. However, there exist some issues that users have to be aware of and need to be discussed. Detailed testing of the functionality and 
robustness of the extension has shown that when calculating land suitability for each functional use, the most important aspect is setting the ratio between physico-geographical and socioeconomic factors, as well as assigning a factor a value of zero (a zero suitability area). The settings of individual parameters affect the results relatively minimally. Only if a setting excludes particular values is the result influenced significantly. Usually, only a considerable change in the weights of multiple factors has a large impact on the final values of the land suitability. When calculating the optimal land use, the most important aspect is setting the preferences of each use and by allowing changes in use for each area. The allowance or restriction of a change of any functional area can affect the outcomes significantly.

The initial setting of the pixel size, which is used throughout the analysis, is also of great importance. In this context, it is also necessary to take into account the size of the area of interest, the required level of detail, the scale of the input data and the used hardware. According to the testing, performing calculations with a pixel size of smaller than $5 \mathrm{~m}$ is not recommended for areas the size of an MEP (the recommended resolution is $10 \mathrm{~m} /$ pixel). All the settings for the calculated results of the extension Urban Planner (land suitability, suggested changes in land use, allowed changes in land use, territorial development scenarios, proposals of optimal land use) were based on relevant documents specifying the limits of land use and further on the basis of detailed discussions and applications of the Saathy pair comparison method by experts from the Municipality of the City of Olomouc and the Regional Authority of the Olomouc Region. The results in the form of the scenarios of development (compromise, landscape, man) reflect the ratios of the factors (95:5, 50:50, 5:95) and were deliberately chosen as scenarios to epitomise the required results as well as possible. The extreme settings of the ratios are partially due to their low sensitivity (at a ratio 75:25, there are only minor changes in the results compared to a basic ratio 50:50).

The results were presented to a wider group of experts from the Department of Urban Planning of the Municipality of the City of Olomouc and from the Department of Urban Planning of the Regional Authority of the Olomouc Region. All the results were offered to them to be evaluated and compared with existing proposals for new development. According their evaluations, the extension produces reasonable outputs and proposes new development in the areas where it makes sense. There are no proposals in the areas that are not suitable from a logical point of view. Most of the proposals for new development in urban plans are located in areas with the highest land suitability calculated by Urban Planner. Experts also agreed that by using this extension all areas in all municipalities can be evaluated objectively using the same approach. No specific places (e.g. residents' preferences or ownership) are preferred, and the evaluation of land suitability is much more accurate.

The greatest potential of the Urban Planner application is planning activities connected with urban plans and the creation of analytical planning materials. Urban Planner can be used as a comprehensive tool to evaluate land suitability and the main principles of sustainable development. The result from the land suitability calculation (areas with the highest values) can be used to assess current or proposed human activities. Based on similarities and differences, 
it is possible to determine what factors were omitted during the creation of the urban plan and what should be improved. The outputs from the second component can be used to evaluate optimal land use according to land suitability calculation and according to the user settings (permitted changes and weights). It is also possible to create several scenarios, compare them and show different possibilities of land development.

By using Urban Planner, it is notably easy to evaluate any area with the same approach in regular intervals. Several scenarios (different users or different approaches) can be calculated easily and used to compare different settings. By using spatial analysis through Urban Planner, the process of urban planning and territorial development can become a better researched subject of study, and subsequent decisions can become better, faster and more accurate. Given the data necessary for operation of the extension and their relative availability in various regions of Czechia, the extension could prove useful for expert territorial planners in Czechia.

\section{References:}

ALBERTI, M., WADDELL, P. (2003): UrbanSIM-A Tool for Land Use Planners. Georgia Basin/Puget Sound Research Conference. Vancouver, 2 pp.

BARAN-ZGLOBICKA, B. (2004): Badania krajobrazove wybranych obszarów lessowych jako podstawa oceny moż liwości wykorzystania terenu w procesie planowania przestrzennego. Ph.D Thesis. UMCS Lublin, 156 pp.

BATTY, M., XIE, Y., SUN, Z. (1999): Modeling urban dynamics through GIS-based cellular automata. Computers, Environment and Urban Systems, 23, No. 3, pp. 205-233.

BORNING, A., WADDELL, P., FÖRSTER, R. (2007): UrbanSIM: Using Simulation to Inform Public Deliberation and Decision-Making, in: Chen, H. et al. (eds.): Digital Government: Advanced Research and Case Studies, Springer-Verlag, pp. 1-24.

BOUGROMENKO, V., ZAKIROV, M. (1999): Geogracom 5W - expert system for sustainable urban and regional transport development. CUPUM '99 Computers in Urban Planning and Urban Management. On the edge of the millenium, Venice.

BRAIL, R.K., KLOSTERMANN, R.E. (2001): Planning Support Systems. ESRI Press, Redlands, $443 \mathrm{pp}$.

BURIAN, J., BRUS, J., VOŽENÍLEK, V. (2013): Development of Olomouc city in 1930-2009: based on analysis of functional areas, Journal of Maps, 9, No. 1, pp. 64-67.

BURIAN, J., ed. (2012): Advances in Spatial Planning. InTech, 366 pp.

BURIAN, J., SORBIOVÁ, K., TUČEK, P., TUČKOVÁ, M. (2012): Possibilities of Delimitation of City Centers Using GIS. Issue 71, Conference Proceedings World Academy of Science, Engineering and Technology, pp. 81-90.

BURIAN, J., STTÁVOVÁ, Z. (2009): Kartografické a geoinformatické chyby v územních plánech. Geografie, 114, č. 3, pp. 179-191.

BURIAN, J. (2008): GIS analytical tools for planning and management of urban proceses. Proceedings from International symposium GIS Ostrava, VŠB-TU Ostrava.

CAO, K., HUANG, B., WANG, S., LIN, H. (2012): Sustainable land use optimization using Boundary-based Fast Genetic Algorithm. Computers, Environment and Urban Systems, 36, No. 3, pp. 257-269.

FEITOSA, F.F., LE, Q.B., VLEK, P.L.G. (2011): Multi-agent simulator for urban segregation (MASUS): A tool to explore alternatives for promoting inclusive cities. Computers, Environment and Urban Systems, 35, No. 2, pp. 104-115.

GARCÍA, A.M., SANTÉ, I., BOULLÓN, M., CRECENTE, R. (2012): A comparative analysis of cellular automata models for simulation of small urban areas in Galicia, NW Spain. Computers, Environment and Urban Systems, 36, No. 4, pp. 291-301. 
GRILL, S., VOREL, J., MAIER, K. (2008): Urban development simulation and evaluation. In: Sborník konference GIS Ostrava 2008, VŠB-TU Ostrava, Ostrava, p. 11.

HE, CH., OKADA, N., ZHANG, Q., SHI, P., ZHANG, J. (2006): Modeling urban expansion scenarios by coupling cellular automata model and system dynamic modeling Beijing, China. Applied Geography, No. 26, pp. 323-345.

HLÁSNÝ, T. (2007): Geografické informačné systémy - Priestorové analýzy. Zephyros, Národné lesnické centrum, Lesnický výzkumný ústav Zvolen, Banská Bystrica, 160 pp.

JANKOWSKI, P., STASIK, M. (2001): Design considerations for space and time distributed spatial decision making. Journal of Geographic Information and Decision Analysis, 1, No. 1 , pp. 1-9.

KALOGIROU, S. (2002): Expert systems and GIS: an application of land suitability evaluation. Computers, Environment and Urban Systems, 26, No. 2-3, pp. 89-112.

KENDERESSY, P. (2003): Integracia GIS do tvorby krajinnoekologického plánu. Životné prostredie, No. 1, pp. 42-44.

KLOSTERMANN, R.E. (1999): What-If? Collaborative Planning Support System. Environment and Planning B: Planning and Design 26, pp. 393-408.

KOLEJKA, J., POKORNÝ, J. (1999): Využití integrovaných prostorových dat v územním plánování na bázi krajinného potenciálu. Integrace prostorových dat. UP Olomouc, Olomouc, $10 \mathrm{pp}$.

KOLEJKA, J. (2001): Krajinné plánování a využití GIS. Česká geografie v období rozvoje informačních technologií. Sborník příspěvků Výroční konference ČGS. UP Olomouc, 11 pp.

KOLEJKA, J. (2003): Geoinformační systémy v aktivním managementu životního prostředí: Data a možnosti hodnocení a modelování rizik. Životne prostredie, No. 1, pp. 19-24.

LAURINI, R. (2001): Information Systems for Urban Planning. London, New York, 368 pp.

LEGATES, R. (2005): Think Globally, act Regionally. ESRI Press, Redlands, 517 pp.

LEGATES, R.T., STOUT, F. (2000): The City Reader. Second edition, Routledge, London, $592 \mathrm{pp}$.

LIGMANN-ZIELINSKA, A., JANKOWSKI, P. (2010): Exploring normative scenarios of land use development decisions with an agent-based simulation laboratory. Computers, Environment and Urban Systems, 34, No. 5, pp. 409-423.

MAANTAY, J., ZIEGLER, J. (2007): GIS for the Urban Environment. ESRI Press, Redlands, $600 \mathrm{pp}$.

MAGLIOCCA, N., SAFIROVA, E., MCCONNELL, V., WALLS, M. (2011): An economic agentbased model of coupled housing and land markets (CHALMS). Computers, Environment and Urban Systems, 35, No. 3, pp. 183-191.

MA, L., ARENTZE, T., BORGERS, A., TIMMERMANS, H. (2007): Modelling land-use decisions under conditions of uncertainty. Computers, Environment and Urban Systems, 31, No. 4, pp. 461-476.

MAIER, K., VOREL, J., ČTYROKÝ, J. (2007a): Simulation model for urban development sustainability appraissal. CORP 2007 Proceedings. Vienna, Austria, 9 pp.

MAIER, K., VOREL, J., ČTYROKÝ, J. (2007b): Comprehensive land-use allocation model. In: Sustainable development of regions. CTU, Faculty of Civil Engineering, Prague, Prague, p. 73.

MARJANOVIĆ, M., BURIAN, J., MIŘIJOVSKÝ, J., HARBULA, J. (2012): Urban Land Cover Change of Olomouc City Using LANDSAT Images. Issue 71, Conference Proceedings World Academy of Science, Engineering and Technology, pp. 75-81.

MATTHEWS, K.B., SIBBALD, A.R., CRAW, S. (1999): Implementation of a spatial decision support system for rural land use planning: Integrating GIS and environmental models with search and optimisation algorithms. Computer and Electronics in Agriculture, 23, $18 \mathrm{pp}$.

PECHANEC, V., BURIAN, J., KILIÁNOVÁ, H., NĚMCOVÁ, Z. (2011): Geospatial analysis of the spatial conlficts of flood hazard. Moravian Geographical Reports, 19, No. 1, 11-19 pp.

PETTIT, C., PULLAR, D. (1999): An integrated planning tool based upon multiple criteria evaluation of spatial information. Computers, Environment and Urban Systems, 23, No. 5, pp. 339-357.

PETROV, L.O., BARREDO, J.I., SAGRIS, V., GENOVESE, E., LAVALLE, C. (2006): Simulating urban and regional scenarios in Europe: study cases in Algarve Province, Portugal 
and Dresden-Prague transport corridor, Germany-Czech Republic. In: Fendel, E., Rumor, M. (eds.): Proceedings of UDMS '06, $25^{\text {th }}$ Urban Data Management Symposium, Delft University of Technology, $16 \mathrm{pp}$.

PICHER, A., ROMERO-CALCERRADA, R. (2006): GIS-based spatial decision support systemfor landscape planning. New system of analysis for decision making. Proceeding of Real CORP 2006, Vienna, 9 pp.

POUŠ, R., HLÁSNÝ, T. (2005): Knowledge based spatio-functional optimisation of urban environment. In: Růžička, J. (ed.): Proceedings from International symposium GIS Ostrava, VŠB-TU Ostrava, $19 \mathrm{pp}$.

RUŽIČKA, M. (2000): Krajinnoekologické plánovanie - LANDEP I. Systémový prístup v krajinnej ekológii, Bratislava, 119 pp.

SAATY, T.L. (1983): Priority Setting in Complex Problems. In: Hansen, P. (ed.): Essays and Surveys on Multiple Criteria Decision Making. Proceedings of the Fifth International Conference on Multiple Criteria Decision Making, Berlin/Heidelberg/New York: Springer, Verlag, pp. 326-336.

SCHALLER, J. (2007): ArcGIS - ModelBuilder Applications for Regional and Development Planning in the Region of Munich (Bavaria). 16. konference GIS ESRI a Leica Geosystems v ČR. Arcdata, Praha.

SILVEIRA, P., DENTIHO, T. (2010): Spatial interaction model of land use - An application to Corvo Island from the $16^{\text {th }}, 19^{\text {th }}$ and $20^{\text {th }}$ centuries. Computers, Environment and Urban Systems, 34, No. 2, pp. 91-103.

VERSTEGEN, J.A., KARSSENBERG, D., VAN DEN HILST, F., FAAIJ, A. (2012): Spatiotemporal uncertainty in Spatial Decision Support Systems: A case study of changing land availability for bioenergy crops in Mozambique. Computers, Environment and Urban Systems, 36, No. 1, pp. 30-42.

VOREL, J., MAIER, K., GRILL, S. (2007): Urban simulation: Decoding alternative futures. REAL CORP 2008 Proceedings, Vienna, Austria, pp. 477-487.

VOREL, J., MAIER, K. (2007): Learning the public preferences for living environment characteristics: the experimental approach. REAL CORP 2007 Proceedings, Vienna, Austria, $12 \mathrm{pp}$.

WADDELL, P. (2002): UrbanSim: Modeling Urban Development for Land Use, Transportation and Environmental Planning. Journal of the American Planning Association, 68, No. 3, p. 22.

ZHANG, Q., BAN, Y., LIU, J., HU, Y. (2011): Simulation and analysis of urban growth scenarios for the Greater Shanghai Area, China. Computers, Environment and Urban Systems, 35, No. 2, pp. 126-139.

ZWICK, P., CARR, M. (2007): Smart Land-Use Analysis, The LUCIS Model. ESRI Press, Redlands, $292 \mathrm{pp}$.

\section{Shrnutí}

\section{„URBAN PLANNER“: MODEL PRO STANOVENÍ SCÉNÁŘU゚ OPTIMÁLNÍHO FUNKČNÍHO VYUŽITÍ ÚZEMÍ}

Příspěvek popisuje navržený model výpočtu krajinného potenciálu a optimálního funkčního využití území a jeho realizaci pomocí extenze pro program ArcGIS s názvem „Urban Planner“. Sestavená extenze umožňuje provádět výpočty krajinného potenciálu, optimálního funkčního využití území, vyhledání konfliktních lokalit a lze pomocí ní vytvářet možné scénáře vývoje území. Při sestavování konceptu funkcionality extenze „Urban Planner“ byla využita zejména metodika LUCIS (Zwick, Carr 2007), metodika LANDEP (Ružička 2000), model What if! (Klostermann 1999) a metodika optimálního funkčního uspořádání krajiny J. Kolejky (Kolejka 2001, 2003).

Extenze je rozdělena na dva hlavní moduly - Výpočet krajinného potenciálu a Optimální využití území, které byly testovány z pohledu funkčnosti a robustnosti. V rámci testování bylo zjištěno, že při výpočtech krajinného potenciálu pro jednotlivá funkční využití hraje 
nejdůležitější roli nastavení poměru mezi fyzickogeografickými a socioekonomickými faktory a dále také ohodnocení faktoru nulovou váhou (plocha s nulovým potenciálem). Dílčí nastavení parametrů ovlivňují výsledky relativně minimálně, pouze v případě nastavení vylučující hodnoty je naopak výsledek ovlivněn výrazně. Obvykle až výraznější změna vah více faktorů ovlivní významnějším způsobem výsledné hodnoty krajinného potenciálu. Při výpočtech optimálního využití hraje důležitou roli nastavení preferencí jednotlivých využití a povolení změn využití na jednotlivé plochy. Povolení či zakázání změny některé funkční plochy může totiž ovlivnit výstupy razantním způsobem.

Všechna nastavení pro vypočtené výsledky extenze Urban Planner (potenciál krajiny, návrhy a povolení změn ve využití území, scénáře vývoje území a návrh optimálního vyžití) vznikla na základě studia příslušných dokumentů vymezujících limity ve využití území a dále na základě detailních diskusí a aplikace Saatyho metody párového srovnávání s pracovníky Magistrátu města Olomouce a Krajského úřadu Olomouckého kraje.

Hlavním výstupem z modelu jsou rastrové vrstvy vypočteného potenciálu a vektorové vrstvy funkční struktury území pro jednotlivé scénáře vývoje, nesoucí atributovou informaci o několika vypočtených hodnotách (potenciál krajiny pro bydlení, potenciál krajiny pro průmysl, povolení změn současné funkční struktury na bydlení, povolení změn současné funkční struktury na průmysl, optimální využití, kategorie krajinného potenciálu pro bydlení, kategorie krajinného potenciálu pro průmysl).

Extenze byla otestována na území ORP Olomouc, ve spolupráci s Odborem územního plánování Magistrátu města Olomouce. Kladně byla hodnocena zejména „reálnost" navrhovaných ploch funkčního využití území. Sestavené výsledky tak mohou být použity jako vhodný podklad pro tvorbu územně analytických podkladů či územně plánovací dokumentace, které zásadním způsobem ovlivňují umístění nových urbanistických aktivit do území. Použitím prostorových analýz prostřednictvím extenze Urban Planner se může územní plánování a územní rozvoj stát více expertní oblastí studia a následná rozhodnutí tak mohou být lepší, rychlejší a přsnější.

Obr. 1 - Schéma výpočtu krajinného potenciálu

Obr. 2 - Nastavení fyzicko-geografických faktorů

Obr. 3 - Nastavení socioekonomických faktorů

Obr. 4 - Ukázka výstupu - krajinný potenciál pro bydlení

Obr. 5 - Schéma výpočtu optimálního využití krajiny

Obr. 6 - Rozhraní extenze pro výpočet optimálního využití krajiny

Obr. 7 - Krajinný potenciál pro bydlení

Obr. 8 - Krajinný potenciál pro průmysl

Obr. 9 - Celkový krajinný potenciál

Obr. 10 - Navržené změny aktuální funkční struktury na optimální strukturu

Authors' affiliation: Palacký University in Olomouc, Department of Geoinformatics, 17. Listopadu 50, 77146 Olomouc, Czechia; e-mail: jaroslav.burian@gmail.com,vilem.pechanec@ upol.cz,vit.vozenilek@upol.cz.

Initial submission, 31 January 2014; final acceptance 27 February 2015.

\section{Please cite this article as:}

BURIAN, J., ŠŤASTNÝ, S., BRUS, J., PECHANEC, V., VOŽENÍLEK, V. (2015): Urban Planner: model for optimal land use scenario modelling. Geografie, 120, No. 3, pp. 330-353. 